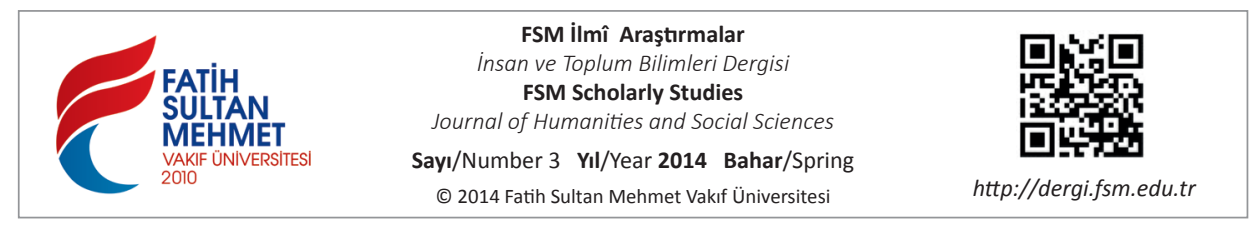

\title{
Understanding the Spirit of Time and Interdisciplinary Perspective in the Interpretation of Hadīth ${ }^{1}$
}

Serdar Demirel *

\begin{abstract}
Throughout history, Muslim scholars have strived to understand the true meaning of the Prophet's (pbuh) ahadīth and interpret them according to the changing conditions of the time. Sciences of Hadith emerged specifically to meet two objectives; first, to distinguish authentic ahadìth from fabricated ones via the chains of report and texts criticism and second, to elaborate it further in order to meet any new conditions or changes introduced into life with the passage of time. Sciences of Hadith and its sub-disciplines are open to further development. The evolving structure of the Sciences of Hadith from its succinct form to its current elaborate structure is clear evident of its dynamic and progressive character. In this study, the researcher focuses on additional critical points in the pursuit of gaining a better understanding of ahadīth, such as comprehending the spirit of the time and adopting an interdisciplinary perceptive.

Keywords: Interpretation, Hadīth texts, Spirit of Time, Interdisciplinary Perspective.

\section{Hadis Yorumunda Zamanın Ruhunu Anlamak ve Interdisipliner Perspektif}

\section{Özet}

İslâm âlimleri Hz. Peygamber'den bize ulaşan hadislerin șaḥiḥ olup olmadıklarını, onların muhtevasını doğru anlamak ve zamanın değişen şartlarına göre yorumlayabilmek için büyük çaba göstermişlerdir. Hadis ilimleri bu gayretlerin tabiî sonucu olarak doğmuş ve zaman içerisinde gelişmiştir. Bu da hadisleri doğru anlamak için konulmuş disiplin ve kaidelerin geliştirilmeye açık dinamik yapısını işaretler. Biz de bu çalışmada hadislerin amacina daha uygun yorumlanabilmesi için çağdaş hadis yorumcusunun daha önceden yapılmış metin anlama tekniklerine ilaveten yeni donanımlara muhtaç olduğunu göstermeye çalıştık. Bu meyanda hadis yorumcusunun içinde yaşadığı çağın ruhuna, bu çağı yöneten dünya görüşüne vakıf olmasının gerekliliğini ve interdisipliner perspektifin sunabileceği müsbet katkıları inceledik.
\end{abstract}

Anahtar Kelimeler: Yorumlama, Hadis metinleri, Zamanın ruhu, İnterdisipliner perspektif.

* Associate Professor, Fatih Sultan Mehmet Vakif University Faculty of Islamic Sciences, Istanbul/Turkey, serdard22@hotmail.com

1 This article was originally a paper titled "Understanding the Spirit of Time and Interpretation of Hadīth and Interdisciplinary Perspective" presented on 3-4 November 2012, at the First International İSAR İstanbul Symposium, Civilization and Change, Istanbul, Turkey. 


\section{Introduction}

Throughout history, Muslim scholars have strived to understand the true meaning of the Prophet's (pbuh) words, deeds and tacit approvals as well as interpret them according to the changing conditions of time. This then led to the formation of various disciplines in Hadith studies. They first embarked on a remarkable and unique project by collecting scattered ahadith and then distinguishing șahih ahadith (authentic ones) from fabricated ones. In this regard, the unique Islamic science of jarh wa ta'dil (criticism of hadìth narrators) was established and with its rigorous founding principles, authentic and fabricated ahadith were distinguished by criticising the chains of narrator and the texts.

Nevertheless, establishing the authenticity of a hadith does not suffice in ensuring the application of religious principles in life because the crux of the Prophet's (pbuh) mission lies in the meaning and interpretation of His ahadith in the context of religion. Thus, clarifying the message of the ahadith for the Muslims, as part of the Prophet's (pbuh) mission, is a critical task. The significance of this arduous task is better understood when the multiple layers of meaning of ahadìth are taken into consideration. For a more detailed analysis, scholars then developed further disciplines such as Gharibul Hadīth, Mukhtalaf al-Hadìth, Asbab Vurudul Hadìth and, al-Nāskh wäl Mansukh.

The principles of understanding hadith correctly and its subdisciplines however are open to further development. The evolving structure of the science of Usül al-Hadìth from its succint form to its current elaborate structure is clear evidence of its dynamic and progresive character. In this study, we aim to focus on some additional critical points in understanding the message of ahadith and their convey once to Muslims.

\section{The Problem of Understanding the Contemporary Time in Hadīth Interpretation}

Fiqh is an area of study which analyzes the rules scattered in the Quran and Sunnah in a methodical way and translates them for application in life. A Faqih is a person who has the ability and the authority to deduct shar ' $i$ regulations from evidence. ${ }^{2}$ Faqihs offer a simplified life to Muslims by merging regulations which ordinate life with all its aspects. Certainly, it should not be forgotten that scholars have different opinions on the same subject. These differences which stem from different perceptions, methods and backgrounds are the depth of this field. In the end, the interpreter's duty is to try to understand the true interpretation of the Divine Will in human life.

2 See. Hayreddin Karaman, the article "Fakih", Türkiye Diyanet Vakfi İslam Ansiklopedisi, İstanbul, Türkiye Diyanet Vakfi Yayın Matbaacılık ve Ticaret İşletmesi, v.12, pp. 127-128. 
A hadith interpreter in a way assumes the responsibility of a Faqih and tries to lay out the Fiqh of sunnah. The interpreter tries to unearth the meaning embedded in the regulations as well as the illah (reason) behind the regulations. He also applies the 'illah of the regulation he has determined on other cases with the same 'illah. This requires understanding the case in its context and determining what Allah's (swt) Will would be in that case. Such an application necessitates an understanding of the regulation and the context in its entirety. Both man and his biological and spiritual aspects as well as his environment in relation to other environments should be scrutinized thoroughly.

Among Islamic disciplines, Figh is one which involves many variables. Therefore, throughout history it has followed a dynamic and developing course. Since Fiqh aims to give direction to changing circumstances based on permanent ones, the dynamic nature of Fiqh compels even those who claim that the door of ijtihad has been closed to often resort to ijtihad.

The dynamic nature of Islamic Figh makes the task of delineating Figh of sunnah arduous for the hadith interpreter. In the past, life flew in a slower course, and socio-cultural as well as socio-political events revolved around permanent parameters. Administrative methods, agrarian lives and lives based on livestock, military structures and scientific activities advanced slowly and thus transformed life slowly. This slow pace enabled the interpreter to have a better understanding of the transforming life and offer solutions to problems.

In modern times, life has gained incredible speed. Activities in all fields ranging from cultural exchange to scientific endeavours have changed rapidly. Especially in the last few decades, advances in technology have given momentum to transformation of cultures and lives. The quality and quantity of the nature of this transformation have perplexed scientists and hadīth interpreters alike.

The biggest handicap faced by the majority of hadith interpreters is the difficulty of grasping the spirit of the contemporary era. Today, scientific disciplines have flourished to a level which prevents man from mastering various fields at the same time. Nevertheless, the hadith interpreter is expected to grasp the worldview of today and determine its philosophical background and how and through what mechanisms it steers life. Only then can the hadith interpreter defend permanent values, analyze changing variables and offer solutions. In this regard, important issues as a separate subtitle have been delineated above.

\section{A Hadīth Interpreter Observing Fiqh of Maqāṣsid}

Throughout history, as in other fields, Muslims have experienced discontinuities in the interpretation of sacred texts. While they went through stagnation in scientific fields, they always able to overcome them, for example, with the systematization of the Fiqh of maqāssid (Founding Principles of Shari'a) 
which was a result of fulfilling such a need.

The Fiqh of maqāsid refers to the spirit of Islamic principles which should be observed while making practical deductions in the method of Figh. In the early history of Islamic Fiqh, the Fiqh of maqāșid was not included in the methodology books. This does not mean that the fuqaha did not know or observe "Maqāșid al-Shari' a". On the contrary, their edifice in general was shaped by maqāsid al-Shari'a. This Fiqh, recorded in the minds of fuqaha rather than Fiqh books then started to weaken in edifice and was overlooked while issuing fatwa. 'Illah (effective cause) in ahkām and resemblances in appearance rather than the main aim were deemed to be sufficient in issuing fatwa. In order to rectify this situation, methodologists systematized the Fiqh of maqāsid and included it in the methodology books.

The concepts of "Maqāṣid al-Shari' $a$ " or "mașlahat" constitute a prominent position in methodology principles because it systematizes the maslahat of people in the world and the hereafter in issues relating to Allah's orders and prohibitions. These principles were included as mașlahat in methodology books and later were formulized as "Maqāsid al-Shari' $a$ ".

In this regard, Maqāșid al-Shari'a was contained in Imam al-Juwayni's (d. 438 AH / 1047 CE) "al-Burhan" for the first time under the category of "essentials" on five main foundations. ${ }^{3}$ Imam Ghazali (d. $505 \mathrm{~h} / 1111 \mathrm{CE}$ ) is one of the pioneers to have analyzed the issue of "maqāșid". His book "Shifa'ul Ghalil fi Bayan ah-Shubah wal Muhayyal wa Masalik al-Ta'lil" and "al-Mustasfa" are especially worthy of attention.

Fahruddîn ar-Rāzi's (d. 606 AH. / 1209 CE.) "al-Mahsūl”, Abdulaziz ibn Abdusselam's (d. 660 AH. / 1262 CE.) work which brought a sufi perspective to the concept of mașlahat "Qāwaid al-Ahkām fi Masalihi'l Anām", Ibn Taymiyya's (d. 728 AH. / 1328 CE.) "Majmāa'ati al-Rasāil vel Masāill" and İbn Qayyim AlJawziyya's (ö. 751 AH. / 1350 CE.) "I'lām'ul Muvakkiīn” are examples of such books. $^{4}$

Abu Ishaq Al-Shatibi's "Al-Muvāfakāt fì Usul al Islāmī"s is a cornerstone in maqāṣid studies. It studies the concept of "Maqāsida-Shari' $a$ " in an unprecedented way by analyzing it as a qat'i (definitive) instead of zanni (hypotetical) and a kulli (complete) instead of juz ' $i$ (partial) principle. As contemporary Muslim thinkers and scholars also continue to pay attention to maqāșid, many books have been

3 See Abdul Mālik bin Abdullah Al-Juwaynī, "al-Burhān F̄̄ Usûl al-Fiqh”, (Vafa, 1418), vol. 2, p.602.

4 Muhammed Khalid Masud, "Islamic Legal Philosophy: A Study of Abu Ishaq al-Shatibi's Life and Thought", Pakistan, Islamic Research Institute, 1977, p. 150.

5 Ibrahim b. Mūsa Al-Shāṭī, "Al-Muvāfakāt Fī Usūl al Fiqh”, Bayrūt, Dār al Marifah. 
written in the field such as Muhammed Al Tāhir ibn Ashūr's (d. CE 1973) book "Makāsīdu al-Sharia 'tul Islämiyye". ${ }^{6}$

It has been argued that the rationale for the systemization of the Fiqh of maqāsid in methodology books as a principle was the lack of attention to the spirit of Islam as the foundation of Fiqh in issuing fatwas. The spirit observed by the fuqaha (jurists) of the early period of Islam was overlooked in the following centuries and issues were reductively interpreted, irrespective of their main context. These approaches necessitated the revival and systemization of this spirit. This principle aims to return to the origin, not detaching itself from Fiqh. On the other hand, it is unacceptable to assume that Fiqh of maqāșid can pose as an alternative to the science of usul al-Fiqh. Such an approach would undermine the significance of Fiqh of maqāssid itself.

While dealing with the physical world affairs, the hadith interpreter should do it holistically; in other words, he should be able to use the opportunities provided by the Fiqh of maqāsid. His comprehension of this essense, especially in modern times, will enable him to stand close to the Divine Will. Thus, understanding the spirit of the contemporary era is essential in accomplishing this task.

Ahadìth on prophetic medicine can exemplify this situation. al-Ṭīb al-Nabawī (Prophetic medicine) texts constitute a substantial number of ahadìth included in hadith literature and Muslim practice. Prophetic medicine refers to the medical practices and advice of the Prophet (pbuh). After his demise, Muslims maintained a reputable literature in this field and wrote books on Prophetic medicine. This literature originates from ahadīth in "Kitāb al-Tib" and "Kitāb al-Mardī" sections of hadīth collections as well as ahadīth included in various other sections of hadīth literature.

As a consequence of the Prophet's (pbuh) role in Islam, the prophetic medical tradition has a considerable impact on Muslims' perception of medicine. This tradition in its entirety has been regarded by many scholars in a divine sense and attributed a religious meaning which has led to a literature esteemed by the Muslim masses. For example, Ibn Qayyūm al-Jawziyyah (d.751/1350) claims that the medical advices and practices of the Prophet (pbuh) have binding nature on believers. In his work on Prophetic medicine he says that this branch of medicine has such wisdom that even the greatest doctors would feel incompetent. $^{7}$

In this regard, it is important to understand who to interact with regard to the

6 al-Ṭāhir Ibn 'Āshūr, “Maqāṣid al-Shariyyah al-Islāmiyyah”, Dār al-Kitāb al-Miṣri \& Dār alKitāb al-Lubnāni, 1. ed, 2011.

7 Muḥamad Ibn al-Qayyūm al-Jawziyya, al-Ṭıbbu al-Nabawī, Ed. 'Abidu al-Ghan̄̄ 'Abd al-Khāliq,, Bayrūt, Dār al-Fikr), p. 1. 
sahih ahadith in this literature. The issue of how to understand the șahih ahadìth in this field, to distinguish the ones of revelation origin and those of traditional Arab medicine and what should be followed and what should be abandoned is an important issue.

The issue of how to understand prophetic medicine in modern times has become controversial for Muslims. al-Ṭīb al-Nabawī means the methods applied and medicine advised by the Prophet Muhammad (pbuh). After the demise of the Prophet (pbuh), a vast literature was built in this field. Medical advices of the Prophet (pbuh) were collected in many works called "al-Tīb al-Nabawî". The main sources of this literature are the "Kitāb al-Tib" and "Kitāb al-Mard̄ā" sections of hadith collections. However, as recognized by experts of the field, the sources are not confined to these two sections; many ahadith on health can be found in other sections of ahadith collections as well.

Due to the status of the Prophet (pbuh) in religion, prophetic medicine tradition penetrated the depths of medical culture in Muslim societies. This tradition is regarded as sacred, it deploys religious values and a literature has been created in this plane. ${ }^{8}$

The Prophet (pbuh) is a rol model who received revelations. Hence, perceiving all of his medical practice and advices as merely historical practices or as an extention of Arab culture is not appropriate. The hadīth interpreter should sort them out and distinguish between revelation-based and non-revelation based, ${ }^{9}$ which enables the usege of this heritage without endangering human life.

The Prophet (pbuh) received revelations and he became a role model for humanity. Thus, studying his advice and applications in medicine only from the historical context and regarding them merely as an extension of the Arab culture cannot be accepted. Instead, the prophetic medicine based on revelation and experience should be evaluated separately by experts. Only then inconsistency of the theoretical framework can be prevented.

When this literature is studied carefully, it will be recognized that prophetic medicine aims to prioritize methods of preservation of health and medication. ${ }^{10}$

8 Many scholars have written books on al-Ṭīb al-Nabawī such as: 'Abd al-Mālik b. Habīb al-Andulūsī, (d.238/852), Muhammad al-Nīsābūry (d.245/860), Aḥmad b. Muḥammad al-Dīnāwāry (d.364/975), Abū Nu'aym al-lsfahāny (d.430/1038), Shams al-Dīd al-Dhahaby (d.748/1347), Ibni Qayyim al-Jawziyyah (d.751/1350), Jalāl al-Dīn al-Suyūṭy (d.911/1505).

9 For detailed information see, Serdar Demirel and Saad Eldin Mansour, "A Theoretical Framework for 'al-Tīb al-Nabawī / Prophetic Medicine' in Modern Times", Revelation and Science Journal, vol. 01, No. 02 (1433H / 2011), pp. 34-45.

10 Imam Al-Bukhāry narrated, "Allah has not sent down an illness without sending down a cure for it."

(Muḥammad Bin Ismā̄îl Al-Bukhāry, Șaḥịh al-Bukhāry, Ed. Mușṭafā Dīb al-Bughā, Bayrūt, 
Even though tools and methods might change, the aims remain the same. Thus, the hadith interpreter should comprehend that the changing means should not be regarded as essential and the main principle of the texts should be upheld.

It is crucial to distinguish revelation-based and non-revelation based medicine related to ahadith and to prioritize the main aims of the prophetic medicine rather than its means and methods. The main aim should be the human health as the Prophet (pbuh) advised medical treatment and emphasized that it is not against fate. ${ }^{11}$ If all of the medical method applied during the time of the Prophet (pbuh) is seen and applied as a religious duty, human health and even life can be jeopardized and this goes against the very main aim of the prophetic medicine. In this regard, Fiqh of maqāṣid is a holistic principle to be observed by the hadīth interpreter.

\section{A Hadīth Interpreter Grasping the Spirit of the Time}

In the modern world, the cultural boundaries between the East and the West, the South and the North are not sharply divided. In a globalised world, while maintaining their local forms to an extent, cultures rapidly resemble to the secular Western culture and adopt profane role models through the channels of the internet, television, film and the media. In this transformation process, however, the internalized profane worldview is often overlooked. Ordinary people do not pay much heed to ideologies; thus, the responsibility of constructing an Islamic life on permanent parameters of Islam lies with Muslim intellectuals.

A hadith interpreter will not be able to grasp the practices permeating the Muslim life as constructed within Western ontological and epistemological contexts without understanding and reckoning with the Western paradigms of edifice. Only with such an understanding can the hadith interpreter assess the similarities in essence and form between the Western and Muslim communities. Sciences of Fiqh and hadith offer the opportunities for such an evaluation with their developing, dynamic structures, but such a task can be achieved only by interpreters with the necessary formation. Omar Ibn Al Khattab's (r.a) statement

Dār Ibn Kathīr al-Yamāma, $3^{\text {rd }}$ ed, v. 5, p. 2151, hadīth no. 5354)

Similarly Imam Muslim narrated, "For every disease there is a cure so if the medicine comes upon the disease it cures it by the will of Allah, the Most High."

(Muslim Bin Ḥajjāj Al-Qushayrī, Șaḥịh Muslim, ed. by Muhammad Fu'ad 'Abd al-Bāqī. Bayrūt, Dār Ihyā al-Turath al- 'Arabī, v. 4, p. 1729, hadìth no. 2204)

Ahadith mentioned in this category do not only rule the permissibility of treatment but advise seeking ways of treatment, causes of illnesses and their cures.

11 Yusuf Al-Qaraḍāwī, "al-Sunnah Mașdrān lil Ma 'rifah Wāl Haḍārah”, Dār al-Shuruq, $2^{\text {nd }}$ ed, pp. 148-172; Yusuf Al-Qaraḍāwī, "Kayfa Nat'āmal Ma 'al Sunnah”,United State of Amerika, $2^{\text {nd }}$ ed, pp. 139-154. 
that "Those who do not know jahilliyyah cannot know Islam"12 summarizes this notion if the word "jahilliyyah" is interpreted as non-Islamic ideas and cultures shaping the life.

The profane and Islamic issues should be understood and evaluated with a worldview penetrating and steering the spirit of the time. Understanding requires a perspective which grasps the profundity of the analyzed issue and making sense necessitates a stance which gives direction to the perception. In order to have a stance, one should understand his own position and the relationship of his stance with others. Bearing in mind the definition of Fiqh as knowing, understanding, comprehending, grasping something ${ }^{13}$, it becomes clear that such an understanding does not only refer to knowing the spirit of principles. Comprehending the spirit of the case is also equally important in order to compliment the assessment of the principle. Thus, Fiqh has a comprehensive meaning referring to hadīth texts as well as the cases to which they are applied because the discipline of Figh consists of principles and attitudes which guide an individual to learn his rights in his favour and against him, and understanding the essence of Fiqh should be a priority. Fiqh derives its sources from the Quran and Sunnah. Hence, a profound understanding of the revelation is essential for a hadith interpreter. Since revelation is to be applied in real life, then understanding dominant paradigms and assessing how and to what extent to interfere should be balanced. In order to minimize inapplicable ijtihad and subjective interpretations of the revelation, knowledge of Shari'a and particular events should be combined because if the essence underlying new events is overlooked, the interpreter will evaluate an event procured within a foreign reality and misinterpret it. In that sense, he will force the boundaries of traditional Fiqh and attribute erroneous interpretations to the event without realizing its depth. Injunctions are often interpreted and victimized by such reductionist approaches while the interpreter remains unaware of the anachronic oddness. The solutions offered by such wellintentioned yet inadequate interpreter of contemporary edifices will inevitably mislead his followers.

In the past, even Bedouin and urban interpreters were distinguished. In modern times, comprehensive perceptions should extent not only to cities but to the entire globe. In an era when all cultural boundaries are blurred, cities, tastes, education methods and economic regimes are almost uniformed; an encompassing perspective is desperately needed. In this regard, the stipulation that the capitalist system overlaps with Islam can exemplify this worldview.

12 Muḥammad b. Ibrāhim b. 'Abd al-Lațif Āl al-Shaykh, "Sharh Kashf al-Shubahāt”, ed. Muḥammad b. 'Abd al-Raḥmān b. Qāsim, (Ṭab" 'Alā Nafaqah Muḥammad b. 'Abd al-Raḥmān b. Qāsim, 1. ed, 1419H), p.27.

13 Hayreddin Karaman, “F1kıh”, Türkiye Diyanet Vakfi İslam Ansiklopedisi, v.13, pp. 1-14. 
Free market economy is widely accepted throughout the world. The necessity of following the rules of the global economy in order to expand in a global economic market and compete with global economic companies is commonly claimed by Muslims. ${ }^{14}$ Those who overlook the differences between Islamic free market and capitalist free market usually refer to these a hadith:

Narrated By Abu Hurayrah: A man came and said: "Apostle of Allah, fix prices. He said: (No), but I shall pray (for blessing)." Again the man came and said: "Apostle of Allah, fix prices. He said: It is but Allah Who makes the prices low and high. I hope that when I meet Allah, none of you has any claim on me for doing wrong regarding blood or property." 15

Anas (ra) narrates: People came to the Prophet (pbuh) and said: "O Prophet (pbuh), prices have risen, please fix prices." The Prophet (pbuh) replied: "Allah makes the prices. He makes your rizq (providence) high and low. I hope that when I meet Allah, none of you has any claim on me for doing wrong regarding blood or property." 16

As indicated by the ahadith above, in Islam, where demand and supply are determinant, free market is essential. Thus, the majority of scholars refuse fixed prices and take fluctating prices as fundamental. ${ }^{17}$ However, this situation is not absolute. Scholars have accepted that authorities can intervene and fix prices when necessary. The priority is to protect the seller and the buyer from damage and establish mutual contentment. The Quran states:

"O you who have believed, do not consume one another's wealth unjustly but only [in lawful] business by mutual consent. And do not kill yourselves [or one

14 Turkey has a fast-growing economy and came second in economic growth pace after China in 2011 at the global scale. The role of the current Justice and Development Party government and its supporting religious businessmen cannot be denied in this success story. Many researchers, on the other hand, drew attention to the congruency between the economic growth of the religious community and free market capitalism. The term "Islamic Calvinists" was coined to mark this compatibility. Both international and local media presented headlines such as "Muslim Protestants" and "Islamic Calvinists". Şükrü Hanioğlu, objects to this term and maintains the intellectuals who can discuss Turkish Muslim community, its cultural problems and history only in Western paradigms in his article "Max Weber - İslami Calvinistler" .

See M. Şūkrū Hanioğlu, "Max Weber - İslami Calvinistler”, Zaman Gazetesi: 02-02-2006. http://www.zaman.com.tr/haber.do?haberno=252508 Retrieved: 25-12-2011.

15 Sulayman Bin Al-Ash'as Abū Dāvūd, "Sunan Abī Dāvūd", Bayrūt, Dār al-Kitāb al- 'Arabī, vol. 3, p.286, hadīth no: 3452 .

16 Muḥammad Bin 'Isā Tirmidhī, "Sunani al-Tirmidhī”, ed. Aḥmad Muḥammad Shākir, Bayrūt, Dār Iḥyā al-Turath al-Arabī, n.d., v.3, p. 605, ḥadīth no: 1314; Abū 'Abd Allāh Aḥmad al-Shaybān̄̄ Ibn Hanbal, "Musnad Ahmad”, Egypt, Mu'assasat Qurțubat, n.d., v. 3, p. 286, hadìth no. 14089.

17 Al-Mubārakfūrī, Muḥammad Bin 'Abdu Rahman bin 'Abdu Rahim, "Tuhfatu al-Aḥwazī Bi Sharḥ̄ al-Jāmī al-Tìrmidhī”, (Bayrūt: Dār al-Kutub al-'Ilmiy), v. 3, p. 433. 
another]. Indeed, Allah is to you ever Merciful" (Nisa: 4/29).

If the mentality of the contemporary liberal economy, its operation and foundational parameters are taken into consideration, it becomes evident that the situation indicated by the ahadith is not compatible and their resemblance is only in form. It is a premise of the discipline of logic, "In order to pass judgements about something, first, you have to grasp it." Therefore, if the hadith interpreter cannot comprehend the essential crux of his subject of study, then his evaluations and judgement will prove to be wrong because free market economy prioritizes "expansion" by all means, unlike Islam which aims for "distribution" and "cooperation". Free market economy needs a market situation where government intervention does not exist or is minimized. This concept does not concern itself with "fair market". Such economic perception bases its structure of production on "fulfilling insatiable desires", not on "legitimate and limited necessities". It aims to expand according to psychological needs established and provoked by itself rather than biological needs.

In sum, it traps man in a vicious cycle where he produces to consume and consumes to produce. It springs from the motto "let them do, let them pass". Interest, sex and alcohol based consumption are the pillars for a vibrant market. Capitalism sanctifies its absolute area of consumption. Free market system detests commercials to be restricted in any way. Thus, it is not bound by "halal" or "haram" restrictions. The only reason why it ventures into "halal food" sector is to benefit from this market and to increase its profit margin.

Modern capitalism came to existence as a result of mental changes, not technology. Hence, free-market-based modern capitalism is a result of secular worldview. It does not allow God in particular, the sacred in general, to interfere in economy and advocates absolute personal property. On the other hand, in Islam, the absolute owner of property and the determiner of prices is Allah (swt). In this sense, proposing that Islam supports the capitalist free market system and referring to the aforementioned hadith is not realistic. Thus, the hadith interpreter should not prioritize the similarities in form but focus on the similarities and differences in essence. Otherwise, without understanding the word view behind the social phenomena, he will justify non-Islamic rulings by misinterpreting hadìth texts.

\section{The Hadīth Interpreter and Inter-disciplinary Perspective}

The hadith interpreter, when relating to his field, should try to benefit from sociology, psychology, politics, medicine and other scientific fields. As these disciplines shape life and shed light on contemporary aspects of rulings, in order to make substantial statements, the hadìth interpreter needs an interdisciplinary perspective. This, however, does not mean that the Fiqh of hadith should be dominated by modern scientific disciplines. 
In order to demonstrate this point, the issue of when a human being gains life right can be given as an example as it constitutes a prominent place in Islamic jurisprudence as well as various religious and judicial understandings.

Does the man gain his life right before or after birth? This question is significant because it is concerning human life based on individual and social laws. The main issue pertaining to human life is the issue of "abortion" as a widespread practice around the world. A 2007 study published in The Lancet, one of the world's bestknown and most respected general medical journals, found that the global rate of abortion was 45.6 million in 1995 and 41.6 million in $2003 .{ }^{18}$

These numbers should suffice to show the seriousness of the issue. Muslim scholars stipulate that a human being gains his right to live in the womb when the spirit is breathed into him. Nevertheless, they dispute about when the spirit is breathed. The source of the dispute is the ambiguous structure of the injunction. Most of the Muslim jurisprudents agree that having abortion, without any exigency, 120 days after conception is haram. This opinion is based on the interpretation that the spirit is breathed into a foetus 120 days later. ${ }^{19}$ Some injunctions refer to 40, 43 and other similar numbers. ${ }^{20}$ Of course the gap between 120 and 40 days

18 http://en.wikipedia.org/wiki/Abortion\#cite_note-Worldwide-0. Retrieved 31-12-2011.

19 'Abd al-Rahmān Ibn Rajab, "Jāmi u Al- 'Ülūm wāl Hikam”, Bayrūt, Dār Al-Ma rifah, 1408 H., p. 48; Ahmed Abdel Aziz Yacoub, “The Fiqh of Medicine”, London, Ta-Ha Publishers Ltd, 2001, p. 211.

20 A hadīth is reported by Al-Bukhārī on the authority of Abdullah Ibn Mas'ud about human development in which Prophet Muhammad said:

"In any one of you, all components of his creation are collected together in his mother's womb by 40 days, and in that it is an alaqah (a clinging object) like that, then in that it is a mudghah (a lump looking it has been chewed) like that. Then God sends an angel and order him with four instructions. He is told to record his livelihood (his sustenance), his age, his deeds, whether he will be miserable or happy, and then the spirit is breathed into him (the soul is acquired)..."

(Al-Bukhārī, v.3, p.1174, ḥadīth no. 3036. See Al-Bukhārī also, v.6, p.2713, ḥadīth no. 7016, Abū Dāvūd, Sunan Abī Dā̀ūd. v.4, p.364, hadīth no. 4710)

The same hadith is also reported by Muslim with a change in the order of some of the words and the phrase "in that" ( $F \bar{l}$ dhalika) was not mentioned in the narration of Al-Bukhārī. Muslim's narration on the authority of the same companion Abdullah Ibn Mas'ud is as follows:

"In any one of you, all components of his creation are collected together in his mother's womb by 40 days, then it is a clinging object ('Alaqah) for a similar (period). Thereafter, it is a lump looking like it has been chewed (Mudghah) for a similar (period). The angel is then sent to him and breathes into him the spirit. Allah sends His angel to it with instructions concerning four things, so the angel writes down his livelihood, his death, his deeds, his fortune and misfortune."

(Muslim Bin Ḥajjāj. Șahīh Muslim, v. 4, p.2036, ḥadīth no. 2643)

Another hadith says:

"The 'Nutfa' stays in the womb for forty nights, then the angel, gives it a shape"

(Muslim, v.4, p.2038, hadīith no.2645) 
is quite big and as the issue pertains to the crucial right of a human being to live, information about the matter should be as precise as possible.

In this regard, can the advanced discipline of "modern medicine" shed light on the issue? Can the hadith interpreter use the opportunities offered by medical science to understand the issue better? Our answer would be "yes". We can summarize this point in the following. Spirit, as a metaphysical being, is not subjected to the experiments in the field of medicine. On the other hand, where the physical aspect of when the spirit is breathed is concerned, all phases of the foetus are relevant to medicine. How many days each phase last, when bones are formed, when the heart starts beating, when the foetus starts moving and when it starts to be affected by its environment can be calculated and monitored closely.

All this concrete information offered by medicine presents us with the opportunity to determine or very closely approximate when the spirit is breathed into the foetus. The Quran and ahadith texts inform us of three fundamental stages that the baby goes through before birth. After these stages, the spirit is breathed. In this regard the Quran states:

Then We placed him as (a drop of) sperm (Nutfah) in a place of rest, firmly fixed; Then We made the sperm into a clinging object ('Alaqa); then of that clot We made a (foetus) lump looking like it has been chewed (Mudghah); then We made out of that lump bones and clothed the bones with flesh: then We developed out of it another creature. So blessed be Allah, the Best to create!" (Al-Muminun: 23/13-14)

The stages mentioned in the injunctions are nutfah (a drop of sperm), 'alaqaa (clinging object) and mudghah (lump looking like it has been chewed). All these stages occur before the breathing of the spirit into the foetus. All Muslim scholars agree that the spirit is breathed immediately after the completion of these stages.

In our opinion, ahadith and other textual sources should be interpreted in accordance with medical observations about the length of these stages ${ }^{21}$ because the medical data are conclusive while the interpretations on the ahadith texts are speculative. In the light of such evidences, rulings on abortion should be reevaluated.

The hadith above also denotes that 'four months' as each stage forty days as well as "the creation of one of you is gathered in his mother's womb in forty days" implies that from "Nutfah" to "Alaqa" and from "Alaqa" to "Mudghah", the creation is completed within forty days.

21 Professor Zaghloul El-Naggar says that the hadith of the Prophet indicates that the first three stages from the "Nutfah" to the "Mudghah" take about 40 days, which is proven by modern scientific facts.

(See. Zaghloul El-Naggar, "Treasures in the Sunnah, A Scientific Approach, Part Two”, Cairo, Al-Falah Foundation, 2005, pp. 31-33. 
This study does not aim to discuss the abortion issue or shed light on its various aspects exhaustively. This issue has been chosen to illustrate the opportunities offered by an interdisciplinary perspective and why the hadith interpreter should focus on such a perspective.

There are numerous ahadith that can be understood better with an interdisciplinary perspective. Some pertain to psychology while others concern political science, economy and many other fields. Another hadīth to be understood in an interdisciplinary framework is the Prophet's utterance of "Yataqarabu'l aswāq" "there will come a time when markets will come closer/ intersect". ${ }^{22}$ Today, globalism is studied from various perspectives; this hadith presents an insightful description of its multiple layers of meaning. For centuries, hadīth interpreters could not explain this hadīth in the sense we understand it today. Like this hadīth, many ahadìth can be fully understood only with the passage of time. It is evident that the most outstanding characteristic of globalism is the merge of markets. Despite the vast distances separating markets, stock markets and production hubs, technology and transportation bring them close together. A businessman living in Tokyo can buy and sell in New York stock markets while another residing in Istanbul can scrutinize Jakarta stock markets minute by minute. Our contemporary era renders national borders meaningless and merges stock markets. Until recently, this hadīth marked a period beyond the horizons of humanity. Instead of leaving the understanding of this hadith in obscurity in ahadith books, this hadith should be reinterpreted in the light of economics, politics and sociology. This shows that interdisciplinary hadith studies will bring us closer to the truth.

\section{Conclusion}

Our observations on the interpretation of hadith texts should not be evaluated separately from the Muslim historical experience. When Islam was expanding, it came across different civilizations. All these civilizations challenged Muslims with their respective civilization paradigms. However defeated they were on the battle field, in the field of civilization they still had much to offer in the philosophical and cultural sense. Muslims faced these challenges that were aimed at epistemological and ontological roots of their religion, took necessary precautions, sifted incompatible elements and transformed what was to be deconstructed. For example, the field of Ilm Kalam is a product of such endeavours. Muslims' political and military superiority gave them confidence and enabled them to confidently analyze challenges posed by other civilizations.

But today, the situation is different, and the task of the contemporary hadith 
interpreter is much more daunting than that of his predecessors because the modern individual and the social issues today are much more complex. Western worldview is imposing its political, military and cultural hegemony at a global scale.

Islamic rhetoric can be formulated only when the hadith interpreter can confidently analyze the phenomena and challenges experienced by the Ummah with its unique edifice of being. For example, using methodological knowledge alone does not suffice to implement Islamic teachings of economy; the hadith interpreter should also be equipped with knowledge of stock markets, modern economy, online commerce and as such.

Hence, Islamic education centers should adopt such curricula to meet these challenging demands and, if necessary, restructure their entire academic institutes. This problem is very challenging but not insurmountable. For this, future hadith interpreters should be equipped with the Islamic system of knowledge and knowledge of the spirit of the time. Muslims can exist in history with their religious identity only through Muslim interpreters who exist in a particular period of history and yet steer variables from an Islamic perspective without deconstructing the edifices of being and life in religion. 


\section{Bibliography}

Abū Dāvūd, Sulayman Bin Al-Ash'as, "Sunan Abī Dāviùd”,Bayrūt, Dār alKitāb al-'Arabī.

Al-Bukhāry, Muḥammad Bin Ismā̄îl, Șaḥịh al-Bukhāry, $3^{\text {rd }}$ edition, Ed. Mușțafā Dīb al-Bughā, Bayrūt, Dār Ibn Kathīr al-Yamāma.

Al-Juwayn̄̄, Abdul Mālik bin Abdullah, "al-Burhān F̄̄ Usûl al-Fiqh”, Vafa, 1418.

Al-Mubārakfūrī, Muḥammad Bin 'Abdu Rahman bin 'Abdu Rahim, "Tuhfatu al-Aḥwazī Bi Sharḥ̄ al-Jāmī al-Tirmidhī”, Bayrut, Dār al-Kutub al-'Ilmiy.

Al-Qaraḍāwī, Yusuf, "al-Sunnah Maṣdrān lil Ma rifah Wāl Haḍ̄àh”, 2 ${ }^{\text {nd }}$ ed., Dār al-Shuruq.

Al-Qaraḍāwī, Yusuf, “Kayfa Nat 'āmal Ma'al Sunnah”,2 ${ }^{\text {nd }}$ ed., United State of Amerika.

Al-Qushayrī, Muslim Bin Ḥajjāj. Șaḥ̄h Muslim, ed. by Muhammad Fu'ad 'Abd al-Bāqī. Bayrūt, Dār Ihyā al-Turath al-'Arabī.

Al-Shāṭ̂ī, Ibrahim b. Mūsa, "Al-Muvāfakāt Fì Usūl al Fiqh”, (Dār al Marifah, Bayrūt).

El-Naggar, Zaghloul, "Treasures in the Sunnah, A Scientific Approach, Part Two", Cairo, Al-Falah Foundation, 2005.

Hanioğlu, M. Şūkrū, "Max Weber - İslami Calvinistler", Zaman Gazetesi: 0202-2006. http://www.zaman.com.tr/haber.do?haberno=252508

Ibn 'Āshūr, al-Ṭāhir, "Maqāṣid al-Shariyyah al-Islāmiyyah”, Dār al-Kitāb al-Mișri \& Dār al-Kitāb al-Lubnāni, 2011.

Ibn Ḥanbal, Abū 'Abd Allāh Aḥmad al-Shaybānī, "Musnad Ahmad”, Egypt, $\mathrm{Mu}$ 'assasat Qurțubat, n.d..

Ibn al-Qayyūm al-Jawziyya, Muḥamad, al-Ṭıbu al-Nabawī, Ed. 'Abidu alGhan̄̄ 'Abd al-Khāliq, Bayrūt, Dār al-Fikr.

Ibn Rajab, 'Abd al-Rahmān, “Jāmi u Al- 'Ulūm wāl Hịkam”, Bayrūt, Dār AlMa'rifah, $1408 \mathrm{H}$..

Karaman, Hayreddin, the article "Fakih" and "F1kıh", Türkiye Diyanet Vakfi İslam Ansiklopedisi, İstanbul, Türkiye Diyanet Vakfı Yayın Matbaacılık ve Ticaret İşletmesi.

Masud, Muhammed Khalid, "Islamic Legal Philosophy: A Study of Abu Ishaq al-Shatibi's Life and Thought”, Pakistan, Islamic Research Institute, 1977.

Muḥammad b. Ibrāhim b. 'Abd al-Lațif Āl al-Shaykh, "Sharḥ Kashf al- 
Shubahāt”, ed. Muḥammad b. 'Abd al-Raḥmān b. Qāsim, (Ṭab' 'Alā Nafaqah Muḥammad b. 'Abd al-Raḥmān b. Qāsim, 1. ed, 1419H).

Serdar Demirel and Saad Eldin Mansour, "A Theoretical Framework for 'alȚīb al-Nabawi / Prophetic Medicine' in Modern Times", Revelation and Science Journal, vol. 01, No. 02 (1433H / 2011).

Tirmidhī, Muḥammad Bin 'Isā, "Sunani al-Tirmidh̄̄”, ed. Aḥmad Muḥammad Shākir, Bayrūt, Dār Iḥyā al-Turath al-Arabī, n.d..

Yacoub, Ahmed Abdel Aziz, "The Fiqh of Medicine”, London, Ta-Ha Publishers Ltd, 2001. 